Journal of Experimental Marine Biology and Ecology

September 2009, Volume 377, Issue 2, Pages 76-83

http://dx.doi.org/10.1016/j.jembe.2009.06.019

(c) 2009 Elsevier B.V. All rights reserved.
Archimer, archive institutionnelle de l'ffremer http://www.ifremer.fr/docelec/

\title{
Nutritional condition of anchovy Engraulis encrasicolus larvae in connection with mesozooplankton feeding catabolism in the southern Bay of Biscay, NE Atlantic
}

\author{
Jean-Pierre Bergeron ${ }^{1, *}$ \\ ${ }^{1}$ IFREMER, Centre de Nantes, Département Écologie et Modèles pour l'Halieutique (EMH), \\ B.P. 21105, F-44311 NANTES CEDEX 03, France \\ *: Corresponding author : Bergeron J. P., Tel. (33) 2 40374162, Fax (33) 2 40374075, email address : \\ jean.pierre.bergeron@ifremer.fr
}

\begin{abstract}
:
The study examines the spatial variations over the French continental shelf of the southern Bay of Biscay (North-East Atlantic) in the nutritional condition of anchovy (Engraulis encrasicolus L.) larvae which was estimated through their DNA/C index. The same cruise yielded quantitative estimates of two metabolic descriptors of the functioning of mesozooplanktonic communities, the enzymes pyruvate kinase (PK) and trypsin, for the first time evaluated simultaneously. The aim was to appraise quality and quantity of matter assimilated by the mesozooplankton and to specify whether the main components of prey ingested by copepods are principally carbohydrates, through PK activity, or protein, under the action of the digestive endopeptidase trypsin. The larval DNA/C index was significantly correlated with PK specific activity but not with trypsin specific activity in the mesozooplankton. This is consistent with previous data on concomitant variations, although on quite different scales, in mesozooplankton PK activity and the larval DNA/C index.
\end{abstract}

Keywords: anchovy larvae, Bay of Biscay, DNA/C index, mesozooplankton, pyruvate kinase, trypsin 


\section{Introduction}

It has recently been recognized that an ecosystem approach is necessary for a better understanding of fish population dynamics (Hall and Mainprize, 2004; Jennings, 2005). It appears to be especially crucial for small pelagic fish in general and anchovy in particular (Fréon et al., 2005; Borja et al., 2008, regarding more specifically the Bay of Biscay anchovy). For example, because anchovy is a short-lived species (Uriarte et al., 1996), classical methods such as VPA (Virtual Population Analysis) are unsuitable for stock assessment. In a short-lived species, a failure in the recruitment process could threaten the preservation of the population. For this reason, a better knowledge of processes regulating the level of the recruitment would be of highest interest. Recruitment generally fluctuates under the influence of various environmental factors, biotic and abiotic, particularly the trophic conditions: these conditions for larvae notably are still considered as playing an important role in their survival, first step of the numerous processes leading to the recruitment. In most cases, changes in the biotic environment are linked to physical forcings acting at quite varying scales of time and space (Alheit and Hagen, 2002; Alheit, 2009).

The scales of relevance for the anchovy (Engraulis encrasicolus L.) population exploited in the Bay of Biscay (North-East Atlantic) are rather large: the spawning season lasts several months, from April to July, and more rarely to early August, with a peak in May-June (Motos et al., 1996), and the spawning area is mainly in the southern part over the continental shelf (Motos et al., 1996). The spawning region for this population is subject to many extrinsic drivers playing roles at mesoscales; it is a patchwork of different systems under the influence of numerous environmental factors such as location and extent of river plumes, upwellings, wind regimes and residual currents (Koutsikopoulos and Le Cann, 1996; Bergeron, 2004; Bergeron et al., 2009).

The mesozooplankton community constitutes the first level of integration of hydroclimatic forcing in the pelagic food web (Banse, 1995); this offers a powerful tool that can be profitably exploited in the characterization of the basic processes on which the system rests. Such forcings affect primarily the metabolism of individuals (Båmstedt, 1986; Kleppel, 1993) and lead to overall changes in the functioning of the community (e.g., among others, Alcaraz et al., 2007). In attempts to assess the main features of this global functioning, the use of biochemical tools, more specifically the measurement of enzymatic activities in samples of the mesozooplankton community, has been advocated (Bergeron, 1983; Bergeron, 1986; Bergeron, 1995). Such methods may be considered as disputable by certain authors (Berges et al., 1993), but the interest in their implementation endures because they provide the fastest, simplest and least expensive ways to assess mesoscale variations in important metabolic features (Packard et al., 1996) and - a most important aspect - because they are compatible with the constraints imposed by the implementation of fisheries research cruises. With this in mind, a new metabolic index has been proposed (Bergeron and Herbland, 2001); this estimates the rate of assimilation of carbohydrate (essentially synthesized by primary producers) by mesozooplankton. This index relates to an enzyme, pyruvate kinase (PK), that works specifically at the end of the glycolysis chain, i.e. for the catabolism of all ingested carbohydrates; it is assumed that PK activity reflects the assimilation of matter and energy drawn by the mesozooplankton community from its phytoplankton diet (Bergeron and Herbland, 2001). The activity of another enzyme has also been measured in an attempt to characterize the assimilation of the protein content of the mesozooplankton diet (protein proportion potentially enhanced by a system based mainly on a microbial loop); this is trypsin, a digestive endopeptidase that has been the object of studies for about three decades (Boucher et al., 1976; Mayzaud and Conover, 1976; Tande and Slagstad, 1982; Båmstedt, 1988; more recently Lischka et al., 2007).

In the spring of 1998, a fisheries research cruise was undertaken in the Bay of Biscay, mainly in order to estimate the abundance and spatial distribution of small pelagic, and especially anchovy, fish populations through the application of acoustics (Scalabrin and Massé, 1993; Massé et al., 1996). Mesozooplankton was sampled for enzyme activity and anchovy larvae 
were analysed in order to determine their nutritional condition in terms of the DNA/C index (Bergeron et al., 1997; Bergeron, 2000).

A fundamental point has to be stated here: although copepods and anchovy larvae occasionally prey on organisms similar in size or quality, the concept underlying measurements in mesozooplankton of enzyme activities does not involve comparison of the diet items of copepods and larvae. Assessment of the quality and quantity of matter assimilated by the mesozooplankton and a study of whether the main components of prey ingested by copepods are principally carbohydrates or protein are ways to characterize the main process that drives this part of the pelagic food web, i.e. to define whether it is new primary production or a microbial loop that is principally involved in supplying the ecosystem with its smallest prey items.

Concomitant variations in PK activity of mesozooplankton and DNA/C of anchovy larvae have already been presented (Bergeron, 2004), although on quite different scales; that study was a comparison of interannual fluctuations of the two indices in a major spawning area under the influence of brackish water flowing out at contrasted rates from a large estuary involved in the enrichment of the marine area. The present study constitutes a first view of regional-scale spatial variations in the DNA/C index of anchovy larvae and its relation to PK and trypsin activities in the surrounding mesozooplankton, with the aim of determining whether these are linked.

\section{Materials and methods}

In 1998, the first leg of the Pegase ("Pélagiques Gascogne") cruise, from 23 May to 2 June, was devoted to an acoustic survey covering the southern part of the Bay of Biscay up to $46^{\circ}$ N (Fig. 1), aboard the French R.V. Thalassa; during this, 42 stations were sampled. During the second leg of the cruise, starting on 5 June and ending on 18, three areas were more intensively investigated, at stations spaced 3 n.m. (5556 m) apart (Fig. 1): the GIR area (for Gironde, the large estuary nearby) sampled between 10 and 13 June (10 stations); the FAC area (from "fer à cheval", the local name given by fishermen) sampled on 15-16 June (10 stations); and the LOB area (for Low Biomass) sampled on 18 June (8 stations). Whereas GIR and FAC are spawning areas, LOB affords a useful contrast because this has been identified as a "desert"; despite its proximity to the Gironde mouth, almost every year, under normal conditions, this area lacks fish and especially anchovy (Motos et al., 1996) and this was verified for 1998 during the first leg of the cruise.

\section{Field sampling procedure}

In the course of the cruise, i.e. over the whole sampled area (WSA) as well as in the more intensively investigated areas (IIAs), at each station the following operations were systematically carried out:

1) temperature and salinity profiles were recorded with a CTD (SeaBird SBE 19);

2) mesozooplankton samples were collected by vertical tows (speed $1 \mathrm{knot}, \sim 0.5 \mathrm{~m} \mathrm{~s}^{-1}$ ) of a classical WP2 net (Anon. 1974), $200 \mu \mathrm{m}$ mesh from $5 \mathrm{~m}$ above the bottom to the surface and from 200 to $0 \mathrm{~m}$ when the samples were taken beyond the continental slope; and 3 ) anchovy larvae were collected by double oblique tows (speed 2 knots, $\sim 1 \mathrm{~m} \mathrm{~s}^{-1}$ ) between the bottom and surface with a "carré net" ( $1 \mathrm{~m}^{2}$ square mouth opening, $380 \mu \mathrm{m}$ mesh).

Chemical and hydrobiological variables

The second leg was exclusively devoted to the IIAs. The same operations as those described above for the WSA were carried out, and furthermore, only during this second leg (IIAs), seawater samples for measurement of nutrients were taken at four to five depths within the photic layer and then filtered on glass fibre filters (Whatman GF/F) with a syringe 
filtration system. Phosphate was analysed on board immediately after sampling on a spectrophotometer (Shimadzu UV 160) with a $10 \mathrm{~cm}$ optical path cell. Samples for mineral nitrogen and silicate measurements were stored in polyethylene flasks, frozen $\left(-20^{\circ} \mathrm{C}\right)$ and analysed later in the laboratory on an autoanalyser apparatus (Skalar). Phosphate, nitrate, mineral nitrogen and silicate concentrations were determined according to the classical methods described by Strickland and Parsons (1972) with the respective detection limit of $0.02,0.05,0.05$ and $0.1 \mu \mathrm{M}$ and the respective precision of $0.01,0.05,0.05$ and $0.1 \mu \mathrm{M}$.

Total chlorophyll a $(\mathrm{Chl} \mathrm{a)}$ and pheopigments were determined by filtration of seawater on Whatman GF/F. $3 \mu \mathrm{m}$ Nuclepore polycarbonate filters and $20 \mu \mathrm{m}$ nylon sieve were used for size fractionation. Filters were frozen $\left(-20^{\circ} \mathrm{C}\right)$ and analysed later by acidification fluorometric procedure in $100 \%$ methanol extracts (Wright et al., 1997).

Samples for bacterial counts were preserved with borate buffered formaldehyde $(2 \%$ final concentration). Bacteria were enumerated by direct counting after staining with DAPI (Porter and Feig, 1980).

\section{Phytoplankton production}

Primary production was measured by in situ incubation of $300 \mathrm{ml}$ seawater in polycarbonate bottles with $10 \mu \mathrm{Ci}$ of ${ }^{14} \mathrm{C}$ from morning to evening (7 am to $9 \mathrm{pm}$ ). After incubation, filtrations were achieved on different pore size filters according to the size fractionation procedure for $\mathrm{Chl}$ a. Filters were placed in scintillation vials with $200 \mu \mathrm{l}$ of $\mathrm{HCl} 1 \mathrm{~N}$, dried overnight at $60{ }^{\circ} \mathrm{C}$ then recovered with $4 \mathrm{ml}$ of scintillation cocktail and stocked until counting at the laboratory with a Tri-Carb liquid scintillation analyser model 1500 (Packard). Time zero filtration was also achieved as controls to substract non biological adsorption on the filter.

\section{Mesozooplankton and anchovy larvae analyses}

The mesozooplankton samples were passed through $5 \mathrm{~mm}$ mesh to eliminate macrozooplankton. The samples were ground in varying volumes (according to estimated biomass collected) of iced distilled water with a Polytron ${ }^{\circledR}$ and immediately frozen in liquid nitrogen; they were thereafter stored at $-90^{\circ} \mathrm{C}$ until analysis in the laboratory (no later than within a 40 days period). After thawing, the crude extract was homogenized again with a Potter-Elvehjem (permitting to obtain an homogenate free of smallest particles, which would prevent an optimal stability of the final enzyme activity estimate) and centrifuged (10 min at $4000 \mathrm{rev} \mathrm{min}^{-1}, 3^{\circ} \mathrm{C}$ ). An aliquot of $200 \mu \mathrm{l}$ of the supernatant fluid was used for enzyme assays or protein determination. Pyruvate kinase (PK) activity was estimated by a widely used method (Bücher and Pfleiderer, 1955), under conditions previously specified (Bergeron and Herbland, 2001). Briefly, the product of the enzyme reaction (pyruvate) serves as substrate for a second enzyme, lactate dehydrogenase (LDH), added in excess in the mixture. The functioning of LDH requires the presence of nicotinamide adenine dinucleotide in its reduced form (NADH) as co-factor; this is oxidized, and its progressive disappearance can be followed by monitoring the decrease in its specific absorbance at $340 \mathrm{~nm}$. This allows PK activity to be assayed by means of a recording spectrophotometer with a water-jacketed cuvette holder for temperature control $\left(25^{\circ} \mathrm{C}\right)$. Enzyme activity, proportional to the rate of change in absorbance, was expressed as specific activity ( $\mu$ mol NADH oxydized $\mathrm{min}^{-1} \mathrm{mg}^{-1}$ protein). Trypsin activity was determined by the "BAPNA method" (Samain et al., 1977). This method requires the use of a synthetic substrate, $N$-benzoyl-L-arginine- $p$-nitroanilide (Erlanger et al., 1961), which is specifically hydrolysed by trypsin with the production of paranitroaniline $(p N A)$. The production rate of $p N A$ can be deduced from the temporal variation of its absorbance at $405 \mathrm{~nm}$ on the same recording spectrophotometer as described above (incubation temperature $40^{\circ} \mathrm{C}$ ); this gives the tryptic activity of the extract. The enzyme activity is expressed as specific activity ( $\mu \mathrm{mol} p \mathrm{NA}$ released $\mathrm{min}^{-1} \mathrm{mg}^{-1}$ protein). Protein (for determination of specific activities) was estimated by a classical method (Lowry et al., 1951) with bovine serum albumin as standard. 
The anchovy larvae collected were specifically and quickly sorted: owing to their greater sensitivity to environmental trophic conditions (Bergeron, 2000), only individuals (4.9-9.7 $\mathrm{mm}$ standard length) at development stages following yolk resorption and earlier than the notochord flexion one were selected (233 individuals, standard length mean value: 7.26 , s.d. $=1.12$ ). Each larva was individually placed in a cryovial, directly frozen at $-40^{\circ} \mathrm{C}$ and subsequently stored at $-30^{\circ} \mathrm{C}$. In the laboratory, larvae were thawed and individually ground in varying volumes (0.8 to $2.4 \mathrm{ml}$ according to size: the volume was adjusted to a theoretical weight taking into account an empirical power function of length) of cold distilled water $\left(4^{\circ} \mathrm{C}\right)$ with a Potter Elvehjem homogenizer. A sub-sample was rapidly placed in a tin capsule for carbon analysis and the remaining sub-sample, after addition of phosphate buffer $(\mathrm{pH} 7.5)$, was immediately processed for DNA determination by a fluorimetric method (Le Pecq and Paoletti, 1966) with modifications (Karsten and Wollenberger, 1972; 1977). Type I DNA (Sigma) from calf thymus was used as the standard. The sample for carbon determination was dried $\left(60^{\circ} \mathrm{C}\right)$ in an oven and then processed in a Perkin-Elmer CHNS/O 2400 analyser. Because in the DNA/C ratio the carbon content $C$ represents the whole of organic molecules and the DNA amount remains constant and representative of the number of cells, a low DNA/C index characterizes a good nutritional state (Bergeron et al., 1991; 1997) and vice versa: $60 \mu \mathrm{g}$ DNA $\mathrm{mg} \mathrm{C}^{-1}$ was defined as the upper threshold at which anchovy larvae are in good condition (Bergeron, 2000).

\section{Results and discussion}

Two major physical processes have led to define the location of the two IIAs representing main spawning areas for anchovy; they occur at two quite close sites, but nevertheless their respective influences are revealed by very contrasting values of sea surface salinity (Fig. 2): the GIR area is situated within the plume of brackish water flowing out of the large Gironde estuary (near $45.5^{\circ} \mathrm{N}$ along the coast, Fig. 2: salinity between 33.5 and 33.75 ) and the FAC area is over the continental slope where tidally-induced internal waves cause an upwelling of deep waters (along the $45^{\circ} \mathrm{N}$ parallel, cf. Fig. 2: salinity nearly 35.5 , very close to the maximum value of 35.6 characteristic of waters of the deep layers in this region of the NE Atlantic).

Studies on mesozooplankton are carried out not only because copepods provide the main diet for anchovy, as confirmed for this region and stage of the seasonal cycle (copepods represent 92 to $98 \%$ in numbers of individuals of the mesozooplankton community: Plounevez and Champalbert, 1999), but also because they are a permanent and omnipresent component in pelagic ecosystems, of which the main functioning features are likely to vary at mesoscales; as such, they serve as biological indicators, revealing the overall effects of the integration of multiple environmental mesoscale factors. In the present study, it is therefore assumed that, rather than suffering from fluctuations in taxonomic composition of mesozooplankton, relative variations in PK and trypsin activities should be indicative of carbohydrates (i.e. photosynthetically produced in phytoplankton cells) or protein (i.e. microbial loop and microzooplankton-based systems) that are the main constituents of the prime components of the food web.

At first glance, the PK specific activity variations over the study area look rather scattered (Fig. 3). However a fact is worth noting, i.e. a highly significant correlation $(R=0.652, n=28$, $p<0.001$ ) does exist in the three IIAs between the PK specific activities and the surface salinity ranging from 32.5 under influence of the Gironde freshwater outflow up to 35.4 , which is indicative of oceanic waters. Obviously such a relationship may not be extended to the whole area covered during the cruise because of the effects of numerous other influential factors. Regarding trypsin specific activity variations, a more coherent horizontal structure appears (Fig. 3) with highest values at coastal stations and lowest values in the central part of the continental shelf. Intermediate values of specific activity not surprisingly accompany the highest ones and moreover tend to gather over the continental slope, where a nutrient 
supply brought by upwelled deep waters may induce an enrichment in protein of the phytoplankton cells (Bergeron et al., 2009).

Anchovy larvae were found and sampled at 12 stations within the IIAs and only a further 13 stations over the entire area covered during the cruise (Fig. 4). There was an interval of 1-3 weeks between the samplings made during the two legs of the cruise. During the early days of the second leg, a wind stress occurred: whereas the wind mean speed was $5.6 \mathrm{~m} . \mathrm{s}^{-1}$ over the period 15 May to 20 June (data from the Chassiron semaphore [see location in Fig. 1], recorded every $3 \mathrm{~h}$ and provided by Météo-France), on 10 June there was a westerly (250$270^{\circ}$ ) of $9-10 \mathrm{~m} \mathrm{~s}^{-1}$ and then on 11 June a more northerly (300-340 ) of $11-14 \mathrm{~m} \mathrm{~s}^{-1}$. This wind event is probably the reason why, surprisingly, the larvae were found more abundantly in the LOB area than in either of the other two IIAs; in fact, this contrast in abundance is probably due to an advection caused by Ekman transport from the GIR area (just to the north of the LOB area, see Fig. 1), as seems to be indicated by the changes in surface salinity (Table 1). Therefore the results from the first (whole sampled region) and second leg (i.e. the IIAs) will be considered as distinct entities.

From the whole sampled area (WSA) during the first leg, the means of a variable number (from 6 to 15) of individual values of the DNA/C index vary between 55 and $104 \mathrm{\mu g} \mathrm{mg}^{-1}$ (Fig. 4). This upper value is a little higher than those determined during a previous ERAG93 cruise before a wind stress described in Bergeron (2000). Although values obtained in the GIR and FAC areas vary within the range of those previously determined in 1993, i.e. between 54 and 84 , the upper mean value for the LOB area is $112 \mu \mathrm{g} \mathrm{mg}{ }^{-1}$. Statistics based on individual values measured in the three IIAs (analysis of variance: ANOVA) show that there are significant differences between the three sites (F-ratio $=10.638 ; p<0.001$ ). The lowest DNA/C values are to a certain extent associated with surface lenses of slightly brackish (salinity 33.5-34.0: cf. Fig. 2) and warmer "old" surface water clearly originating from the coast (these data are collected from vertical CTD recordings at all of the WSA and IIA stations, the ODV software (Schlitzer, 2001) provides a horizontal view of the hydrological structure); it is notably the case for individuals sampled at three stations located along the $44^{\circ} 40 \mathrm{~N}$ transect (Fig. 4). The possible influence of the biotic environment on the nutritional condition of anchovy larvae was investigated by comparison with metabolic descriptors for mesozooplankton, i.e. PK and trypsin specific activities: ANOVA applied to these data shows that, for PK, significant differences also exist between the three sites (F-ratio $=7.275 ; p=$ 0.003 ), whereas there is no difference for trypsin (F-ratio $=0.752 ; p=0.482$ ). The DNA/C index did not show any relationship with variations in trypsin activity (Table 2), but in the IIAs was significantly correlated with PK activity. For the WSA, the $p$ value indicates that the correlation does not reach the same degree of significance; however, the data from the WSA show a trend similar to that shown in the IIAs and, in any case, clearly contrast with the complete lack of correlation between larval DNA/C and the trypsin specific activities in mesozooplankton (Table 2). Therefore it seems acceptable to tentatively compare the parameters of the regression equations of the relationships linking DNA/C and PK (Table 2); this shows that at a nil PK specific activity the DNA/C value was similar for the two sets of data: 107 (WSA set) and 113 (IIAs set): statistics show that the two values fall within not distinguishable confidence intervals at $95 \%$, so they are not significantly different $(\alpha=0.05)$. Moreover, these values are interestingly close to the highest DNA/C values measured in the present data set and in a priori unfavourable areas in a previous study (Bergeron, 2000); therefore one may hypothesize that DNA/C $\sim 110 \mu \mathrm{g} \cdot \mathrm{mg}^{-1}$ is indicative of the limit beyond which larvae are severely starving. The slopes of the regression lines are markedly different: -8.78 (WSA) and -19.88 (IIAs). This indicates that, as PK activity increases, the DNA/C values more rapidly reach favourable levels in the IIAs; it is not surprising that this is observed in habitats preferentially occupied by anchovy larvae, i.e. in areas chosen a priori to be more intensively investigated because of the importance of their supposed role in the spawning success, mainly linked to the presence of breeders in abundance regularly observed for numerous spawning seasons (Motos et al., 1996). The relationship given by the data from the WSA is slightly more scattered (smaller correlation coefficient); this may be attributed to the larger scale, over which the probability increases that some unknown, or at 
least unidentified, factors may occur and inevitably confuse the relationship. The inverse proportionality shown by these relationships is due to the fact that the lowest values of the DNA/C index indicate best larval nutritional condition and vice versa (Bergeron et al., 1991; 1997). Therefore, this result means that, at least in 1998 in the studied area, a direct relationship links the nutritional condition of the anchovy larvae to variations in mesozooplankton PK specific activity. This is quite in accordance with previous results on concomitant interannual variations, between 1997 and 1998, in both indices determined within the Gironde estuary plume (Bergeron, 2004).

Except in highly productive systems, communities of small-sized phytoplankters bloom in large areas of the ocean, as has been observed in the present study region at a similar stage of the seasonal cycle (Herbland et al., 1998); because they are nutrient-limited, these communities produce large quantities of carbohydrates, a widely observed and described phenomenon (e.g. Myklestad, 1977; Granéli et al., 1999; Granum et al., 2002). High values of PK specific activity in mesozooplankton samples theoretically imply that traces of carbohydrates exist in the diet of their main components, i.e. copepods. It is often assumed that the prey of copepods is generally of comparable sizes with the prey of most species of fish larvae, especially larval early stages of small pelagic fish (essentially phytoplankton). This may be so, but this view is far from being the most important point. Enhanced PK activity in copepods means that the basic biological production processes rest essentially on small-sized phytoplankton production, leading to greater proportion of carbohydrates in the food finally available for copepods.

An examination of a selection of a few hydrobiological variables collected during the IIAs sampling (Table 4: Daniel Delmas and Claire Labry, Dept. DYNECO, IFREMER, personal communication) allow to go further in the analysis of environmental factors justifying main features of mesozooplankton enzyme activities and DNA/C index variations. First these three areas are not totally nutrient depleted regarding mineral nitrogen or silicate (Table 4), whereas phosphorus appears clearly as a limiting factor of phytoplankton production. The difference of the respective proportions of ammonium and mineral nitrogen between two close areas, GIR and LOB, shows the importance of a remineralisation process in providing a source of nitrogen for the primary production when direct supply of mineral nitrogen is lower. There is a strong difference, nearly one order of magnitude, in $\mathrm{Chl}$ a concentrations between the GIR and FAC areas where good nutritional conditions were observed for anchovy larvae, but the percentage of small-sized $(<3 \mu \mathrm{m})$ phytoplankton cells is the highest (70) and large cells are nearly absent ( $2 \%$ only): this means that the phytoplankton cell sizes in the FAC area are quite suitable for the ingestion by anchovy larvae; moreover, in terms of production, these cells represent $75 \%$, i.e. the highest proportion out of the three IIAs. In the GIR area, the proportions of the three size classes of cells are much less different, but a basic primary production is regularly maintained owing to the proximity of the Gironde estuary, which continuously provides nutrients. Lastly, the main difference between the LOB area and the two other IIAs is in the nitrogen quantities available, with the lowest mineral nitrogen and the highest ammonium percentage, over $50 \%$, twice that estimated in the GIR area. Finally, as previously demonstrated in a recent article (Bergeron et al., 2009), a direct relationship links spatial variations of PK specific activities to the ratio (bacterial C I phytoplankton $\mathrm{C}$ ), which reflects different maturation states of the phytoplankton community (Cho and Azam, 1990) In the present study, mean values of this ratio determined for each of the three IIAs are closely correlated to the PK activity mean values: $R^{2}=0.9997, p<0.001$, this confirms the significance of PK specific activity in mesozooplankton communities.

Although copepods and fish larvae eat similar-sized prey, the nature and composition of their diet may differ substantially. In general, according to the literature, copepods in the Bay of Biscay preferentially consume nano- and microzooplankton, such as heterotrophic flagellates or ciliates (Sautour et al., 2000; Vincent and Hartmann, 2001). In contrast, anchovy larvae feed mainly on stages of copepods, i.e. the nauplii and early copepodites of small species, as reported for Engraulis encrasicolus in Mediterranean environments (Conway et al., 1998; Tudela et al., 2002), for E. mordax in Californian waters (Mullin, 1995) and for E. anchoita in three Patagonian spawning areas (Viñas and Ramirez, 1996). 
A study of the biochemical composition of eggs and larval stages of several species of small pelagic fish in 1995 in the Bay of Biscay (Riveiro et al., 1997; Guisande et al., 1998) showed that, especially in E. encrasicolus, the lipid percentage decreased while protein and carbohydrate percentages increased as larval size increased. It is likely that the main portion of these carbohydrates is almost continuously supplied by feeding upon carbohydrateenriched prey. This might indicate that carbohydrates play a prominent role in the metabolism of anchovy larvae. Similarly the importance of carbohydrate-rich particulate matter, as phytoplankton produced by pulses of wind-induced coastal upwelling in the northern Alboran Sea, has been recently demonstrated (Garcia et al., 2006) for the feeding and growth of post-flexion sardine larvae.

At this stage of the analysis, two possibilities can be considered: is there a causality in this relationship, so that the nutritional condition of anchovy larvae depends to some extent on autotrophic production of carbohydrates? Or does the PK activity of the mesozooplankton simply reflect a suitable maturation state of the pelagic system, which would be beneficial to, among others, anchovy larvae inhabiting this system? Whatever its cause, the link between enhanced PK specific activity in mesozooplankton and good nutritional condition of anchovy larvae seems, even if not totally significant according to statistical rules, to be substantially coherent. If further studies confirm this assumption, this would allow estimates of the probability of larval fish survival on broad scales thanks to a very convenient tool because collecting a mesozooplankton sample in the field is easier and less time-consuming than sorting small and delicate fish larvae and, moreover, it provides a global view of the functioning of the biotic environment of the fish population. This could open up new perspectives in fisheries ecology.

\section{Acknowledgements}

The author is greatly indebted to several colleagues in the EMH Department: Paul Bourriau and Daniel Halgand for their help in field sampling and sample processing; Nathalie Schreiber for carrying out biochemical analyses; and Cathy Dejouy for drawing the figures. Daniel Delmas and Claire Labry (Dept. DYNECO, IFREMER) kindly contributed to describe the hydrobiological environment with their data, which is very much appreciated. Warm thanks are due to Jacques Massé, manager of the IFREMER Project "Écologie des Petits Pélagiques", and to Captain, officers and crew of the R.V. Thalassa. This study was carried out within the framework of the "Programme National sur le Déterminisme du Recrutement" (PNDR), a French contribution to the GLOBEC (SPACC) International Programme.

\section{References}

Alcaraz, M., Calbet, A., Estrada, M., Marrassé, C., Saiz, E., Trepat, I. 2007. Physical control of zooplankton communities in the Catalan Sea. Prog. Oceanogr. 74, 294-312.

Alheit, J., 2009. Consequences of regime shifts for marine food webs. Int. J. Earth Sci., 98, 261-268.

Alheit, J., Hagen, E., 2002. Climate variability and historical NW European fisheries. In: Wefer, G., Berger, W.H., Behre, K.E., Jansen, E. (Eds.) Climate Development and History of the North Atlantic Realm. Springer-Verlag, Berlin, pp. 435-445.

Anon., 1974. Zooplankton sampling. Monographs on oceanographic methodology, 2. The Unesco Press, Paris.

Båmstedt, U., 1986. Chemical composition and energy content. In: Corner, E.D.S., O'Hara, S.C.M. (Eds.). The Biological Chemistry of Marine Copepods. Clarendon Press, Oxford, pp. 1-58.

Båmstedt, U., 1988. Interspecific, seasonal and diel variations in zooplankton trypsin and amylase activities in Kosterfjorden, western Sweden. Mar. Ecol. Prog. Ser. 44, 15-24. 
Banse, K., 1995. Zooplankton: pivotal role in the control of ocean production. ICES J. Mar. Sci., 52, 265-277.

Bergeron, J.-P., 1983. Approche systémique des potentialités de production secondaire pélagique: l'évolution printanière en province néritique. Oceanol. Acta vol. sp. $n^{\circ} 4,15-19$.

Bergeron, J.-P., 1986. Approche systémique des potentialités de production secondaire pélagique: inférences de fluctuations interannuelles. Oceanol. Acta 9, 291-303.

Bergeron, J.-P., 1995. Aspartate transcarbamylase activity for the assessment of mesozooplankton production: new aspects from oceanic areas. ICES J. Mar. Sci. 52, 305313.

Bergeron, J.-P., 2000. Effect of strong winds on the nutritional condition of anchovy (Engraulis encrasicolus L.) larvae in the Bay of Biscay, Northeast Atlantic, as inferred from an early application of the DNA/C index. ICES J. Mar. Sci. 57, 249-255.

Bergeron, J.-P., 2004. Contrasting years in the Gironde estuary (Bay of Biscay, NE Atlantic) springtime outflow and consequences for zooplankton pyruvate kinase activity and the nutritional condition of anchovy larvae: an early view. ICES J. Mar. Sci. 61, 928-932.

Bergeron, J.-P., Boulhic, M., Galois, R., 1991. Effet de la privation de nourriture sur la teneur en ADN de la larve de sole (Solea solea L.). ICES J. Mar. Sci. 48, 127-134.

Bergeron, J.-P., Person-Le Ruyet, J., Koutsikopoulos, C., 1997. Use of carbon rather than dry weight to assess the DNA content and nutritional condition index of sole larvae. ICES J. Mar. Sci. 54, 148-151.

Bergeron, J.-P., Herbland, A., 2001. Pyruvate kinase activity as index of carbohydrate assimilation by mesozooplankton: an early field implementation in the Bay of Biscay, NE Atlantic. J. Plankton Res. 23, 157-163.

Bergeron, J.-P., Delmas, D., Koueta, N., 2009. Determining how the pelagic ecosystem over the continental shelf of the Bay of Biscay (NE Atlantic) functions: An approach using mesozooplankton enzyme activities as descriptors. Estuar. Coast. Shelf Sci. 82, 254-264.

Berges, J.A., Roff J.C., Ballantyne, J.S., 1993. Enzymatic indices of respiration and ammonia excretion : relationships to body size and food levels. J. Plankton Res. 15, 239-254.

Borja, Á., Fontán, A., Sáenz, J., Valencia, V., 2008.Climate, oceanography, and recruitment/ the case of the Bay of Biscay anchovy (Engraulis encrasicolus). Fish. Oceanogr.,17, 477493.

Boucher, J., Laurec, A., Samain, J.-F., Smith, S.L., 1976. Etude de la nutrition, du régime et du rythme alimentaire du zooplancton dans les conditions naturelles par la mesure des activités enzymatiques digestives. In: Persoone, G., Jaspers, E. (Eds.). Proceedings of the 10th European Marine Biology Symposium. Vol. 2. Universa Press, Wetteren, Belgium, pp 85-110.

Bücher, T., Pfleiderer, G., 1955. Pyruvate kinase from muscle. In: Colowick, S. P., Kaplan, N. O. (Eds.). Methods in Enzymology. Vol. 1. Academic Press, London, pp. 435-440.

Cho, B. C., Azam, F., 1990. Biogeochemical significance of bacterial biomass in the ocean's euphotic zone. Mar. Ecol. Prog. Ser. 63, 253-259.

Conway, D.V.P., Coombs, S.H., Smith, C., 1998. Feeding of anchovy Engraulis encrasicolus larvae in the northwestern Adriatic Sea in response to changing hydrobiological conditions. Mar. Ecol. Prog. Ser. 175, 35-49.

Erlanger, B.F., Kokowsky, N., Cohen, W., 1961. The preparation and properties of two new chromogenic substrates of trypsin. Arch. Biochem. Biophys. 95, 271-278.

Fréon, P., Cury, Ph., Shannon, L., Roy, C. 2005. Sustainable exploitation of small pelagic fish stocks challenged by environmental and ecosystem changes: a review. Bull. Mar. Sci. 76, 385-462.

García, A., Cortés, D., Ramíres, T., Guisande, C., Quintanilla, J., Alemany, F., Rodríguez, J. M., Álvarez, J. P., Carpena, Á. 2006. Field comparison of sardine post-flexion larval growth and biochemical composition from three sites in the W Mediterranean (Ebro river coast, bays of Almeria and Málaga). Sci. Mar. 70 (Supl. 2), 79-91.

Granéli, E., Carlsson, P., Turner, J. T., Tester, P. A., Béchemin, C., Dawson, R., Funari, E., 1999. Effects of N:P:Si ratios and zooplankton grazing on phytoplankton communities in the 
northern Adriatic Sea. 1. Nutrients, phytoplankton biomass, and polysaccharide production. Aquat. Microb. Ecol. 18, 37-54.

Granum, E., Kirkvold, S., Myklestad, S.M., 2002. Cellular and extracellular production of carbohydrates and amino acids by the marine diatom Skeletonema costatum: diel variations and effects of N depletion. Mar. Ecol. Prog. Ser. 242, 83-94.

Guisande, C., Riveiro, I., Solá, A., Valdés, L., 1998. Effect of biotic and abiotic factors on the biochemical composition of wild eggs and larvae of several fish species. Mar. Ecol. Prog. Ser. 163, 53-61.

Hall, S.J., Mainprize, B., 2004. Towards ecosystem-based fisheries management. Fish Fish., $5,1-20$

Herbland, A., Delmas, D., Laborde, P., Sautour, B., Artigas, F., 1998. Phytoplankton spring bloom of the Gironde plume waters in the Bay of Biscay: early phosphorus limitation and food-web consequences. Oceanol. Acta 21, 279-291.

Jennings, S., 2005. Indicators to support an ecosystem approach to fisheries. Fish Fish., 6, 212-232.

Karsten, U., Wollenberger, A., 1972. Determination of DNA and RNA in homogenized cells and tissues by surface fuorometry. Anal. Biochem. 46, 135-148.

Karsten, U., Wollenberger, A., 1977. Improvements in the ethidium bromide method for direct fluorometric estimation of DNA and RNA in cell and tissue homogenates. Anal. Biochem. 77, 464-470.

Kleppel, G.S., 1993. On the diets of calanoid copepods. Mar. Ecol. Prog. Ser., 99, 183-195.

Koutsikopoulos, C., Le Cann, B., 1996. Physical processes and hydrological structures related to the Bay of Biscay anchovy. Sci. Mar. 60 (Supl.2), 9-19.

Le Pecq, J.B., Paoletti, C., 1966. A new fluorometric method for RNA and DNA determination. Anal. Biochem. 17, 100-107.

Lischka, S., Giménez, L., Hagen, W., Ueberschär, B., 2007. Seasonal changes in digestive enzyme (trypsin) activity of the copepods Pseudocalanus minutes (Calanoida) and Oithona similis (Cyclopoida) in the Arctic Kongsfjorden (Svalbard). Polar Biol. 30, 1331-1341.

Lowry, O.H., Rosebrough, N.J., Farr, A.L., Randall, R.J., 1951. Protein measurement with Folin-phenol reagent. J. Biol. Chem. 193, 265-275.

Massé, J., Koutsikopoulos, C., Patty, W., 1996. The structure and spatial distribution of pelagic fish schools in multispecies clusters: an acoustic study. ICES J. Mar. Sci. 53, 155160.

Mayzaud, P., Conover, R.J., 1976. Influence of potential food supply on the activity of digestive enzymes of neritic zooplankton. In: Persoone, G., Jaspers, E. (Eds.). Proceedings of the 10th European Marine Biology Symposium. Vol. 2. Universa Press, Wetteren, Belgium, pp. 415-427.

Motos, L., Uriarte, A., Valencia, V. 1996, The spawning environment of the Bay of Biscay anchovy (Engraulis encrasicolus L.). Sci. Mar. 60 (Supl.2), 117-140.

Mullin, M.M., 1995, Nauplii of the copepod, Calanus pacificus, off southern California in the El Niño winter-spring of 1992, and implications for larval fish. J. Plankton Res. 17, 183-189.

Myklestad, S., 1977. Production of carbohydrates by marine planktonic diatoms. II. Influence of the N/P ratio in the growth medium on the assimilation ratio, growth rate, and production of cellular and extracellular carbohydrates by Chaetoceros affinis var. willei (Gran) Hustedt and Skeletonema costatum (Grev.) Cleve J. Exp. Mar. Biol. Ecol. 29, 161-179.

Packard, T.T., Berdalet, E., Blasco, D., Roy, S.O., St-Amand, L., Lagacé, B., Lee, K., Gagné, J.P., 1996. Oxygen consumption in the marine bacterium Pseudomonas nautica predicted from ETS activity and bisubstrate enzyme kinetics. J. Plankton Res. 18, 1819-1835.

Plounevez, S., Champalbert, G., 1999. Feeding behaviour and trophic environment of Engraulis encrasicolus (L.) in the Bay of Biscay. Estuar. Coast. Shelf Sci. 49, 177-191

Porter, K.G., Feig, Y.S., 1980. The use of DAPI for identifying and counting aquatic microflora. Limnol. Oceanogr. 25, 943-948.

Riveiro, I., Verea, M., Guisande, C. 1997, Relationships between protein, carbohydrate and lipid content with size and temperature in wild marine fish larvae. J. Fish Biol. 51 (suppl. A), 417. 
Samain, J.-F., Daniel, J.-Y., Le Coz, J.-R., 1977. Trypsine, amylase et protéines du zooplancton: dosage automatique et manuel. J. Exp. Mar. Biol. Ecol. 29, 279-289.

Sautour, B., Artigas, F., Delmas, D., Herbland, A., Laborde, P., 2000. Grazing impact of micro- and mesozooplankton during a spring situation in coastal waters off the Gironde estuary. J. Plankton Res. 22, 531-552.

Scalabrin, C., Massé, J., 1993. Acoustic detection of the spatial and temporal distribution of fish shoals in the Bay of Biscay. Aquat. Living Resour. 6, 269-283.

Strickland, J.D.H., Parsons, T.R., 1972. A practical handbook of seawater analysis, 2nd edn. Bull. Fish. Res. Board Can. 167, 1-130.

Tande, K.S., Slagstad, D., 1982. Ecological investigation of the zooplankton community of Balsfjorden, Northern Norway. Seasonal and short-time variations in enzyme activity in copepodite stage V and VI males and females of Calanus finmarchicus (Gunnerus). Sarsia 67, 63-68.

Tudela, S., Palomera, I., Quílez, G., 2002. Feeding of anchovy Engraulis encrasicolus larvae in the north-west Mediterranean. J. Mar. Biol. Ass. UK 82, 349-350.

Uriarte, A., Prouzer, P., Villamor, B., 1996. Bay of Biscay and Ibero Atlantic anchovy populations and their fisheries. Sci. Mar. 60 (Supl.2), 237-255.

Viñas, M.D., Ramirez, F.C., 1996. Gut analysis of first-feeding anchovy larvae from the Patagonian spawning areas in relation to food availability. Arch. Fish. Meeresforsch. 43, 231256.

Vincent, D., Hartmann, H.J., 2001. Contribution of ciliated microprotozoans and dinoflagellates to the diet of three copepod species in the Bay of Biscay. Hydrobiologia 443, 193-204.

Wright, S.W., Jeffrey, S.W., Mantoura, R.F.C., 1997. Evaluation of methods and solvents for pigment extraction. In: Jeffrey, S.W., Mantoura, R.F.C., Wright, S.W. (Eds.), Phytoplankton pigments in oceanography: guidelines to modern methods. UNESCO Publishing, Paris, pp. 261-282.

Schlitzer, R., 2001. Ocean Data View. http://www.awi.bremerhaven.de/GEO/ODV. 


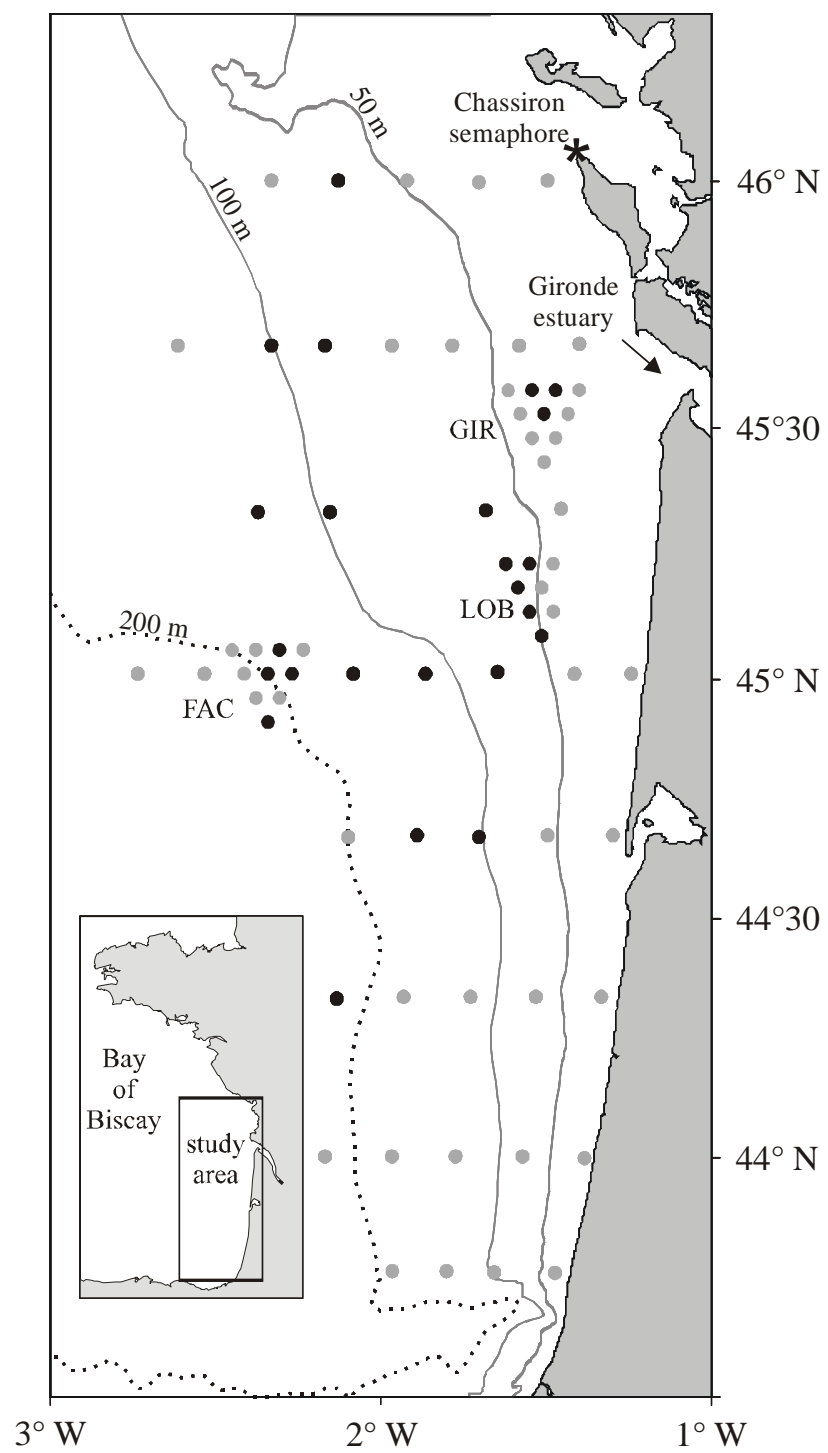

Figure 1

Map of the study area in the Bay of Biscay (see insert) showing the whole of the sampled stations. Black dots indicate stations where anchovy larvae were collected. 


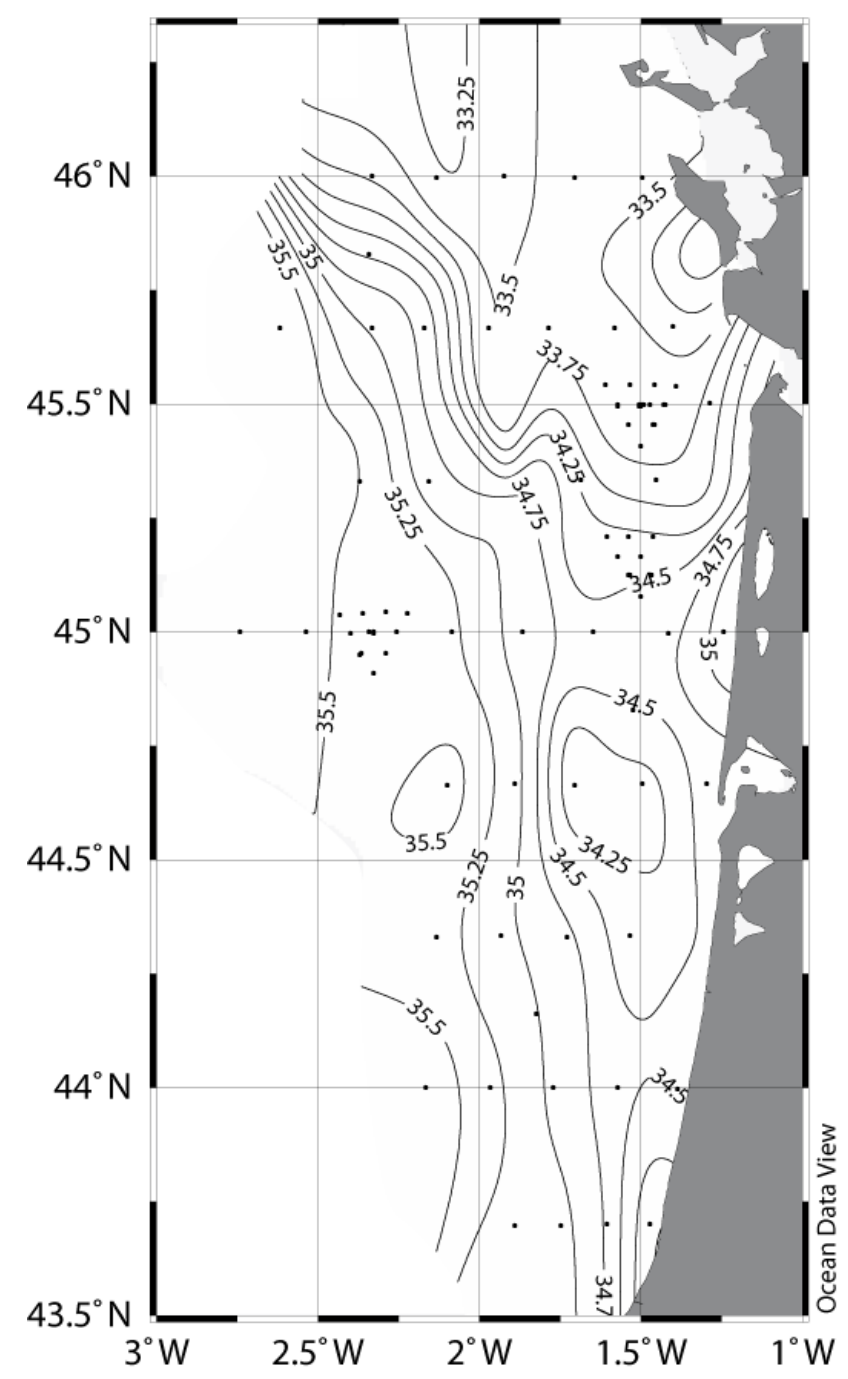

Figure 2

Map of sea surface salinity (more exactly at $5 \mathrm{~m}$ depth) variations in the whole sampled area during the first and second legs (geographic coordinates are here expressed in a decimal system), mapped out with the help of the ODV (Ocean Data View) software (Schlitzer 2001) 

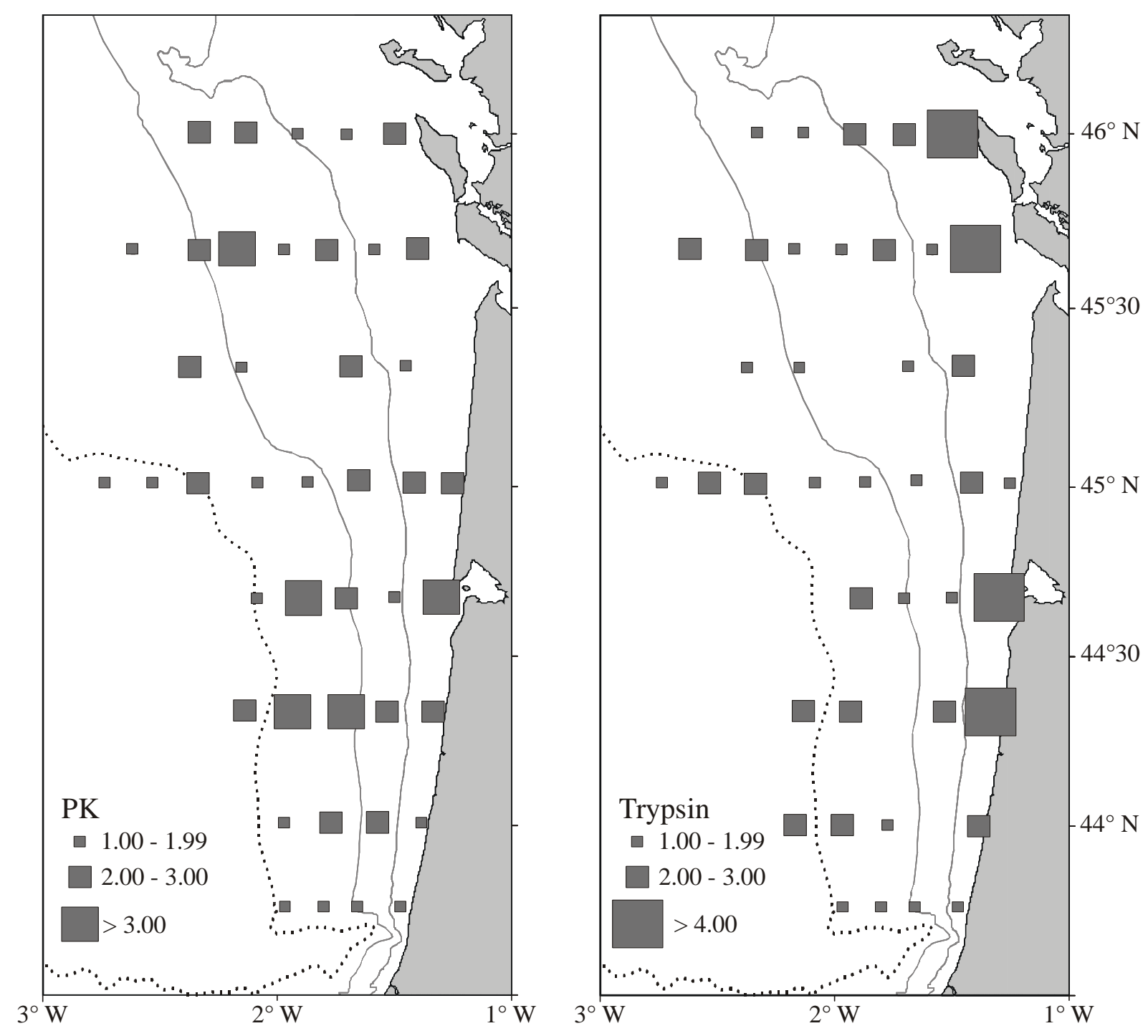

Figure 3

Patterns of spatial variations of mesozooplankton PK specific activity (on the left) and trypsin specific activity (on the right; note a discontinuity in the progression of the values, there is a "hole" with no value within the range 3-4) during the first leg (WSA). 


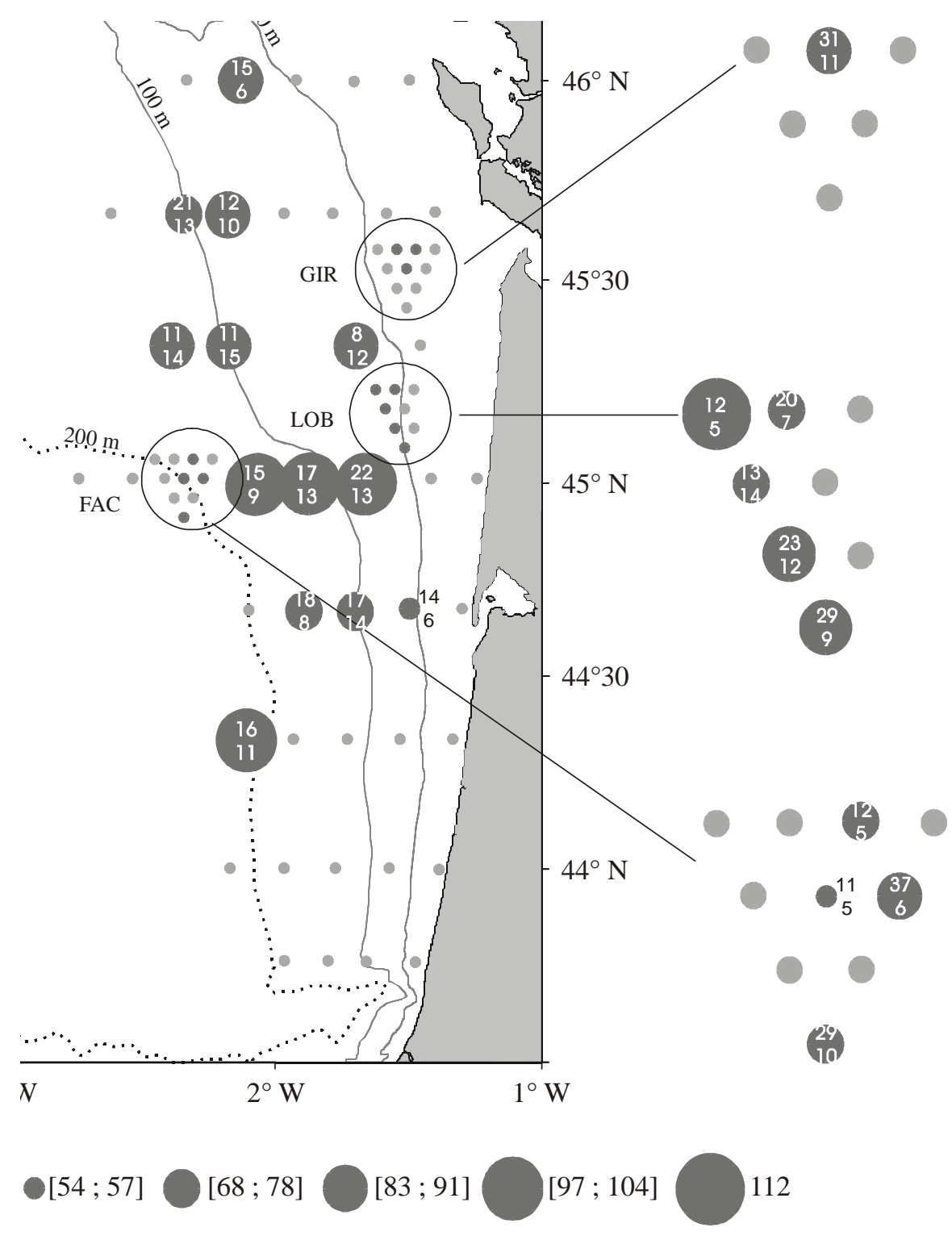

Figure 4

Area in the southern Bay of Biscay investigated during the Pegase 98 cruise. Light grey dots for sampling stations without anchovy larvae. Results from the intensively investigated areas (IIAs) are enlarged on the right side of the map. Sizes of the dark grey dots are proportional to the mean values of the DNA/C index (in $\mu \mathrm{g}$ DNA $\mathrm{mg} \mathrm{C}^{-1}$ ) evaluated in anchovy larvae sampled in these stations: five increasing sizes of dark grey dots represent five groups of mean values, each belonging to a specific range. Two numbers are presented within each mark, the standard deviation (top) and the number of larvae analysed (below). 


\section{Tables}

Table 1

Mean sea surface salinity measured in the three intensively investigated areas (IIAs).

\begin{tabular}{lccl}
\hline & $\mathbf{n}$ & mean & SD \\
\hline & & & \\
GIR & 10 & 33.6 & 0.506 \\
FAC & 10 & 35.3 & 0.082 \\
LOB & 8 & 34.2 & 0.369 \\
LOB (3 northern stations) 3 & 33.8 & 0.12 \\
\hline
\end{tabular}

\section{Table 2}

Correlation coefficients for the linear relations between DNA/C mean values in anchovy larvae (y) and enzyme specific activities in mesozooplankton (x) for the whole sampled area (WSA) and intensively investigated areas (IIAs).

Equations for PK specific activities in $\mathrm{x}$ :

$$
\begin{aligned}
& \text { WSA: } y=-8.78 x+107 \\
& \text { IIAS: } y=-19.88 x+113
\end{aligned}
$$

\begin{tabular}{lllll}
\hline & & $\mathbf{R}$ & $\mathbf{p}$ & DF \\
\hline \multirow{4}{*}{ PK } & & & & \\
\multirow{4}{*}{ Trypsin } & WSA & -0.5367 & 0.0736 & 10 \\
& IIAS & -0.7173 & 0.0152 & 9 \\
& WSA & 0.0422 & 0.8964 & 10 \\
& IIAS & -0.1685 & 0.642 & 8 \\
\hline
\end{tabular}




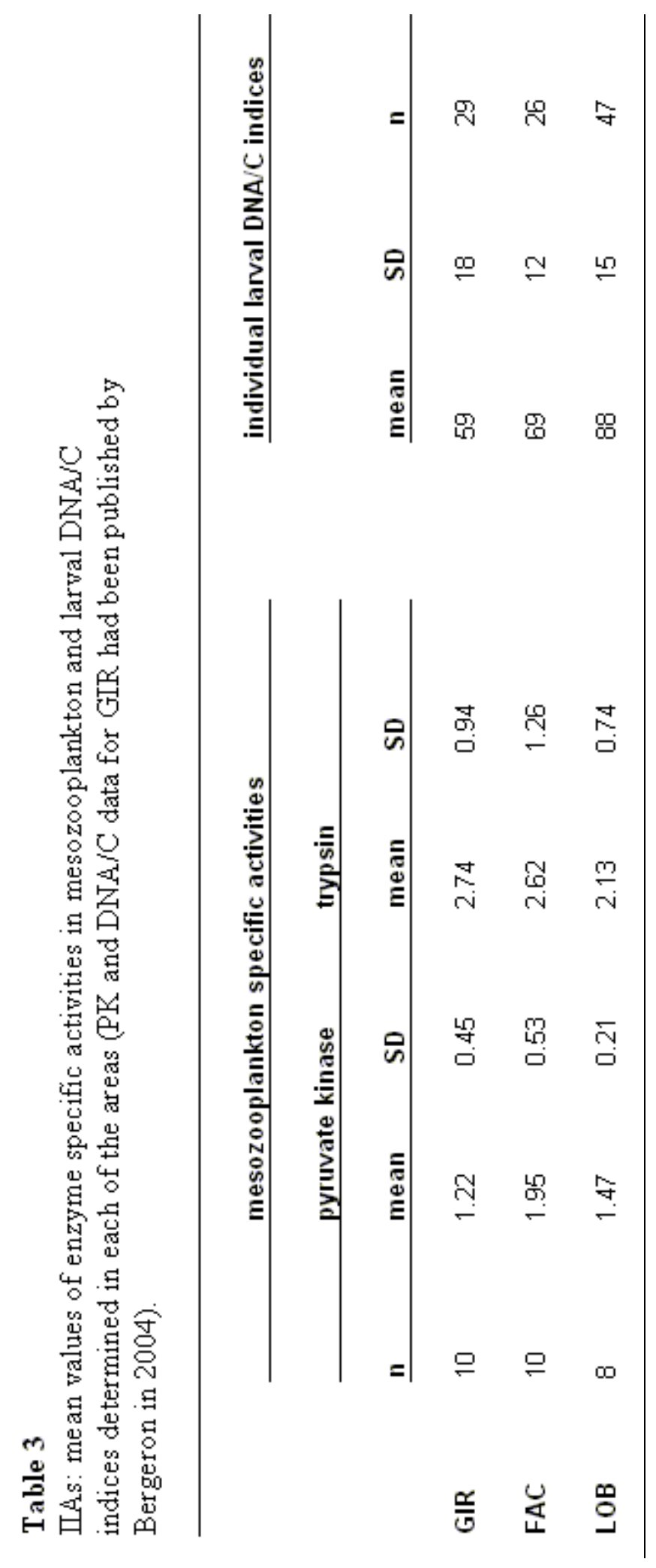




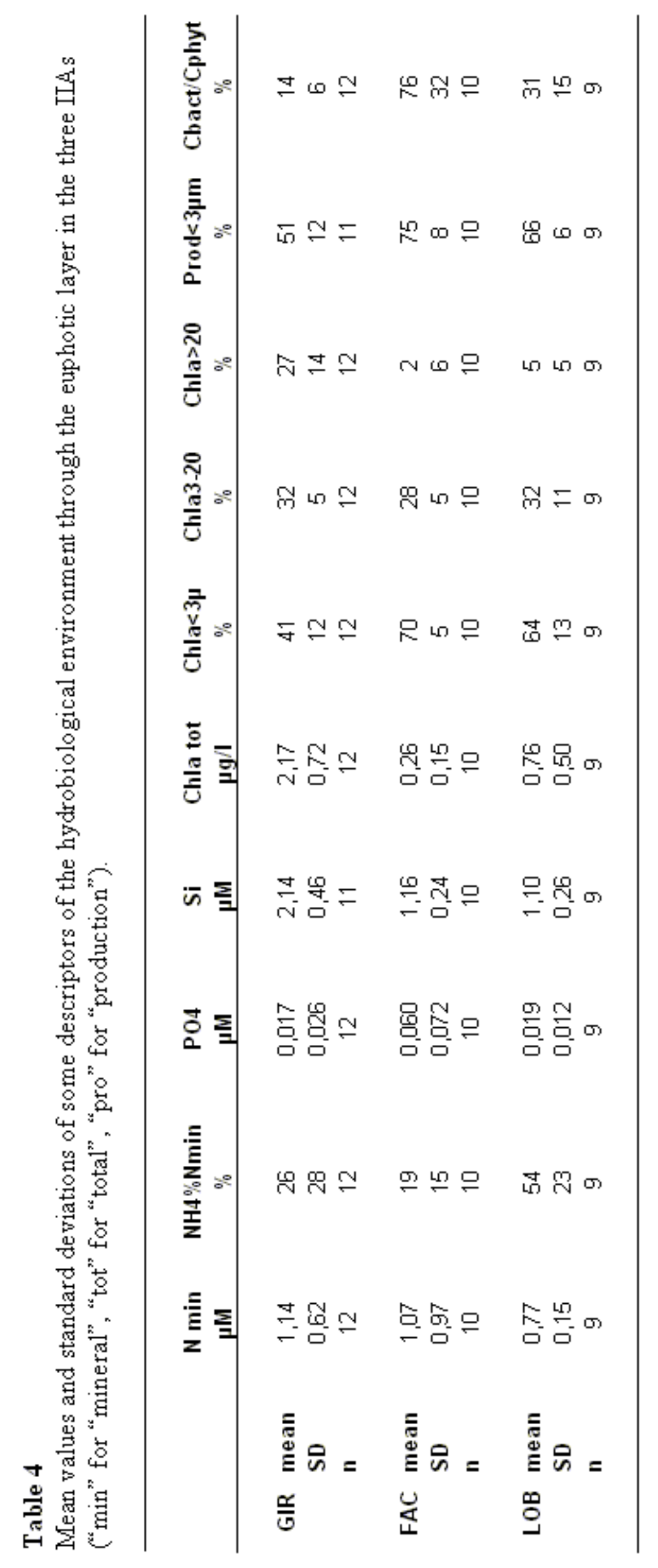

